\title{
Endovenous laser therapy for varicose vein
}

\author{
Erwin Mulia, Iwan Dakota, Hananto Andriantoro, RWM Kaligis, Ismoyo Sunu
}

Department of Cardiology and Vascular Medicine, Faculty of Medicine, Universitas Indonesia, National Cardiovascular Center Harapan Kita, Jakarta, Indonesia

\begin{abstract}
Abstrak
Laser telah menjadi teknologi yang bermanfaat dalam tatalaksana inkompetensi katup vena terutama pada vena-vena superfisial. Ablasi termal endovena menggunakan teknologi laser yang dipandu oleh ultrasonografi memberikan alternatif terapi selain tindakan bedah vena saphena. Tingkat keberhasilan yang tinggi, komplikasi kecil, dan teknik invasif minimal merupakan kelebihan dari teknik ini dibandingkan dengan pengobatan terdahulu. Pada ilustrasi kasus ini, kami jabarkan terapi laser endovena untuk pengobatan varises vena saphena magna. Pengembangan terapi laser endovena masih diperlukan,melalui pemantauan jangka panjang dan sistem pelaporan yang seragam maka hal ini dapat terwujud. (Med J Indones. 2013;22:117-20)
\end{abstract}

\begin{abstract}
Laser has become a useful technology in treating venous incompetence especially superficial venous disease. Introduction of endovenous thermal ablation through endovenous laser therapy helped by duplex ultrasound guidance has provided an alternative for traditional saphenous vein stripping. High success rate, minor complications, and minimally invasive technique provide the advantages over traditional treatment. In this case illustrated, the endovenous laser therapy used for great saphenous varicose vein. Yet, future development in endovenous laser therapy is still needed and only long term follow-up and uniform reporting standards will provide the answers. (Med J Indones. 2013;22:117-20)
\end{abstract}

Keywords: Endovenous laser therapy, great saphenous vein, varicose vein

Laser has been acknowledged as a technology used in vascular field since 25 years ago. But first usage was in human arteries. Ten years after, laser emerged as a useful technology in human veins, treating venous incompetence. In fact, the treatment of venous disease especially superficial venous disease, has undergone radical change in the last 10 years. Better understanding of venous anatomy and physiology provided by duplex ultrasound in the evaluation of venous disease and the introduction of endovenous thermal ablation through endovenous laser therapy (EVLT) have not only provided alternative to traditional saphenous vein stripping but also challenged this traditional treatment. ${ }^{1,2}$

First reported usage of endovenous laser was to ablate a segment of refluxing great saphenous vein (GSV). ${ }^{3}$ The aim of ablating superficial venous reflux as the first step in the treatment of symptomatic varicose veins remains unchanged. Minimally invasive procedure to ablate superficial venous reflux and decreased incidence of neovascularization in the groin secondary to preservation of superficial venous drainage of the abdominal wall will favor this procedure more than surgical approach. ${ }^{1,2}$

In this case illustration we would like to share our first experience with EVLT for varicose vein.

\section{Case illustration}

In 2010, a 45 years old males patient (BMI $33.6 \mathrm{~kg}$ / $\mathrm{m}^{2}$ ) came with varicose veins. Three days before hospitalization, he complained of pain on his right lower limb varicose veins. Pain was exacerbated with movement and direct pressure. He had varicose since five years ago with no prior symptoms. He also had hypertension, diabetes mellitus, and dyslipidemia, which were treated with amlodipine, metformin, pioglitazone and simvastatin. He had been given micronized, purified flavonoidic fraction. Physical examination revealed inflammation on varicose veins just above right popliteal region and medial part of proximal right tibial region (Figure 1). Lower limb arteries pulsation were equal and normal. ECG was normal sinus rhythm. Chest X-ray revealed elongated aortic segment with no sign of cardiomegaly and congestion. Laboratory results found no sign of infection, D-dimer was normal with blood

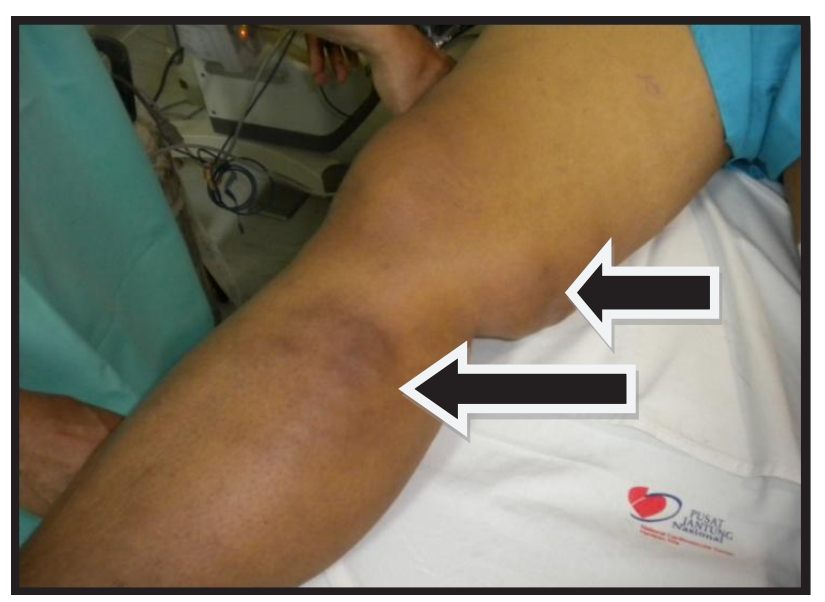

Figure 1. Varicose veins 

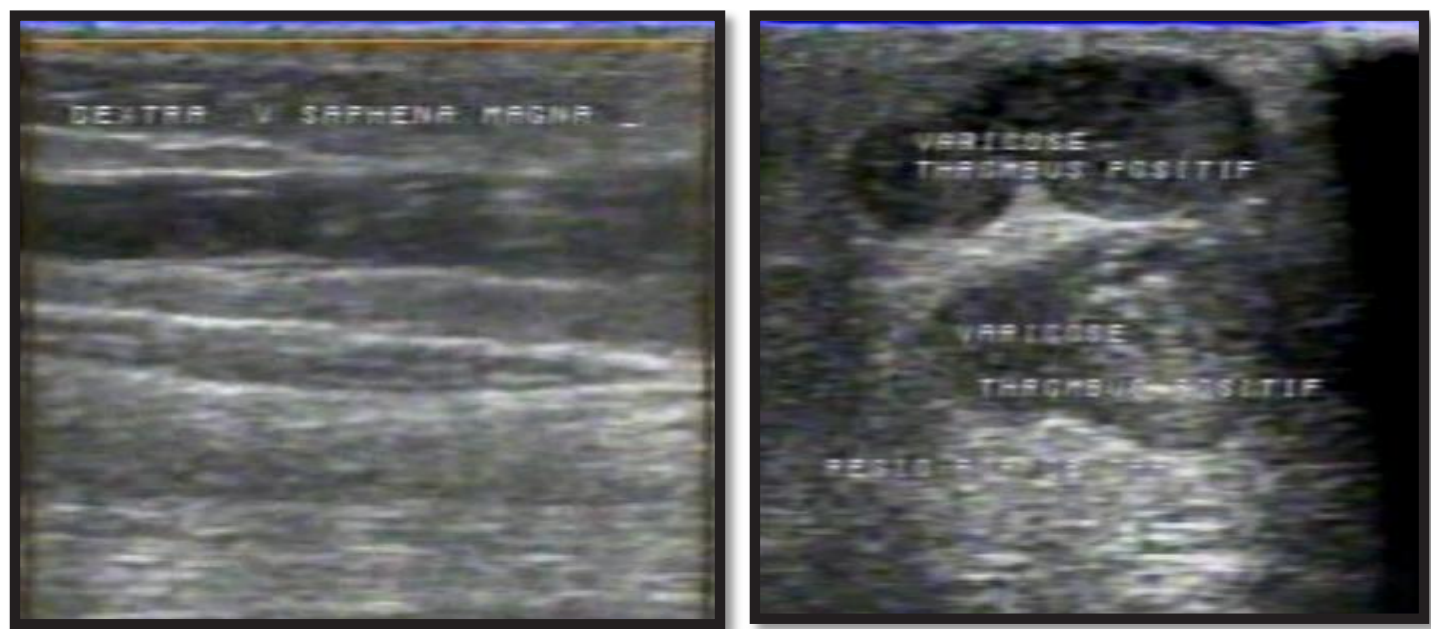

Figure 2. Thrombophlebitis of right GSV

glucose $(281 \mathrm{mg} / \mathrm{dL})$ and HbA1C 6.8. Echocardiography showed diastolic dysfunction with normal dimension, ventricular function and valves.

Femoral duplex ultrasound revealed moderate chronic venous insufficiency of both limbs and thrombophlebitis (thrombus and inflammation) at medial part of right GSV (from distal part of superficial femoral region to proximal tibial region) without deep vein thrombosis (Figure 2). Patient was planned to undergo hybrid procedure which included surgery and EVLT.

The patient was fully sedated. First, venous ligation was performed at right sapheno-femoral junction. Guidewire access is obtained through the segment of vein (proximal of aneurysmatic varicose vein) to be treated followed by laser catheter (1320 nm wavelength). The vein was emptied by compression and instillation of perivenous tumescent anesthesia. In addition to enhancing contact of the vein wall with the treating catheter for therapeutic effectiveness, tumescent also provides analgesia and a heat sink around the treated vein thereby decreasing heat-related injury to surrounding tissues and reducing the incidence of skin burns and paresthesias. The final position of laser catheter was rechecked under ultrasound, then the laser fiber and sheath were withdrawn together at rate $0.5 \mathrm{~mm} / \mathrm{s}$ to $1 \mathrm{~mm} / \mathrm{s}$ to deliver 5 watt to 8 watt at $50 \mathrm{~Hz}$ frequency. After completion of laser procedure, complete occlusion of the GSV was confirmed by ultrasound examination. Then the surgeon continued to perform excision of the aneurysmatic vein (Figure 3). Bleeding was minimal. This hybrid procedure took time two and a half hour.

Patient was given additional enoxaparine for two days. Further ultrasound follow up showed good result, with no re-opening of occluded GSV. Then patient was discharged and given compression stocking.
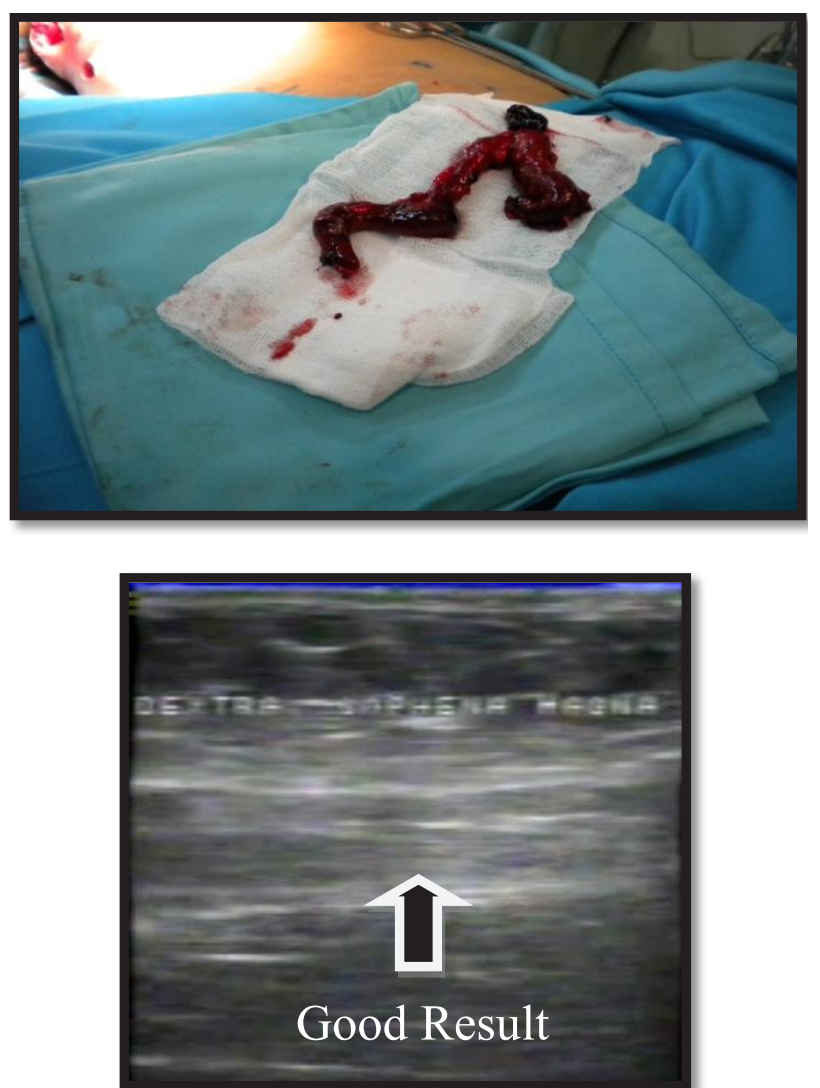

Figure 3. Excised aneurysmatic varicose vein \& ultrasound follow up of GSV

\section{DISCUSSION}

\section{Mechanism of action}

The mechanism of action of EVLT involves thermal damage of the vein wall that results in destruction of the intima by a process of selective photothermolysis and collagen denaturation of the media, with eventual fibrotic occlusion of the vein over time. ${ }^{1}$ 
The exact mechanism of laser-induced thermal damage remains unknown. Two mechanisms are postulated. First, indirect heating and damage of the vein wall by intravascular steam bubble generation by the laser probe, which heats up to a temperature of $1000^{\circ} \mathrm{C}$, resulting in thrombotic occlusion of the vein. Second, direct heating of an empty vein, probably through a thin film of blood, resulting in direct damage to the vein wall., ${ }^{1,4}$

The currently available lasers include hemoglobinspecific laser wavelengths (HSLWs; 810, 940, and 980 $\mathrm{nm}$ ) and water-specific laser wavelengths (WSLWs; 1320 and $1319 \mathrm{~nm}$ ) with debatable differences in mode of action. ${ }^{2}$ We used water-specific laser wavelength $1320 \mathrm{~nm}$ which is related with lesser complications (Figure 4).

\section{Pre-procedure evaluation}

The detailed pre-procedure duplex ultrasound examination is very important. The identification of all refluxing venous segments and their ablation is the key to minimizing recurrence of varicose vein. There are no absolute contraindication to EVLT. Other relative contraindications include uncorrectable coagulopathy, liver dysfunction, limiting local anesthetic use, immobility, pregnancy, and breast-feeding. ${ }^{1}$ Contraindications were not found in this patient.

\section{Post-procedure care}

A graduated compression stocking is applied to the leg from the base of the toes to the groin and kept on at all times for two weeks and when upright/ ambulatory thereafter for six weeks. Immediate and frequent ambulation is encouraged. ${ }^{1,2}$ This patient was also given compression stocking and further ambulatory care was encouraged.

\section{Complications}

Minor complications are reported in some patients which include bruising around the puncture site, transient paresthesias, superficial phlebitis, skin burns or pigmentation. The incidence of skin burns and paresthesias has decreased significantly with increasing experience with the technique.?

Patients undergoing EVLT more likely to have tight and pulling sensation along the medial thigh that is secondary to thrombotic occlusion of the vein and thrombophlebitis. The more serious complications of deep venous thrombosis (DVT) and extension of thrombus into the femoral vein, but pulmonary embolism is extremely rare. There is a learning curve, with decrease in the incidence of all complications with experience. ${ }^{8}$ In this patient no complications occurred.
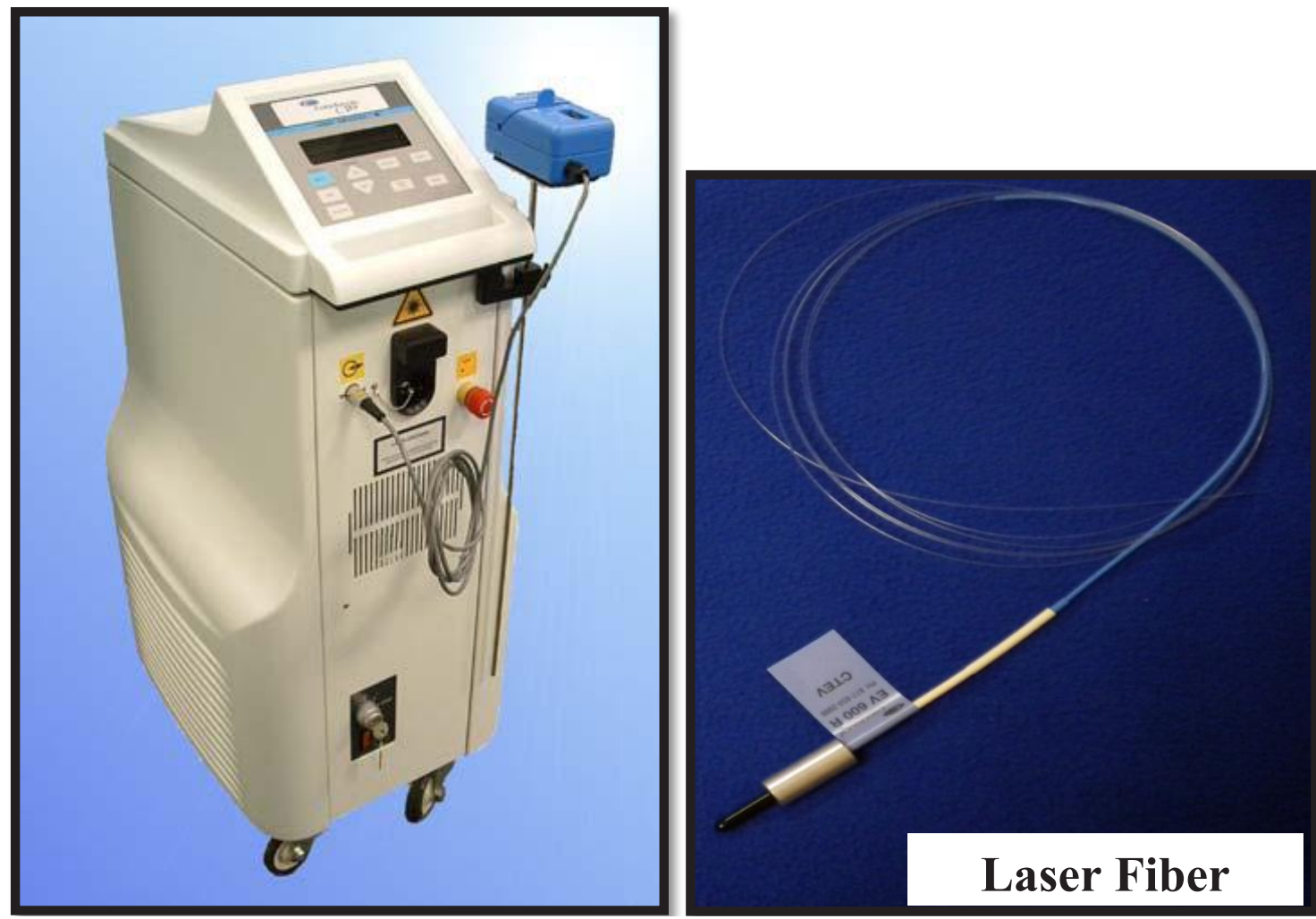

Figure 4. Endovenous laser equipments 
Ligation of veins before EVLT and usage of low molecular heparin may have part in this outcome.

Early success in terms of ablation of the refluxing vein is about $90-95 \%$ with EVLT. ${ }^{9}$ The success of EVLT has been shown to be dependant upon the amount of laser energy delivered, with no occlusion and early reopening of the GSV seen more frequently using energy less than $70 \mathrm{~J} / \mathrm{cm} .{ }^{10,11}$ Recanalization after thrombotic occlusion seems to be the factor causing procedure failure. Long term failure such as persistent or recurrent reflux or patency of treated saphenous vein segments, has also been shown to be related to non treatment of large tributaries or perforating veins. ${ }^{12}$ Compared with conventional stripping, significantly decreased postoperative pain, faster return to normal activity, superior quality of life and overwhelmingly better patient acceptance with equal efficacy of treatment have been demonstrated with this minimally invasive technique. One year follow up in this patient showed improved symptoms and signs (Figure 5). Future developments in this field must mandate standardization of technical aspects, follow-up imaging and reporting of this minimally invasive technique of superficial venous ablation. ${ }^{1,13}$

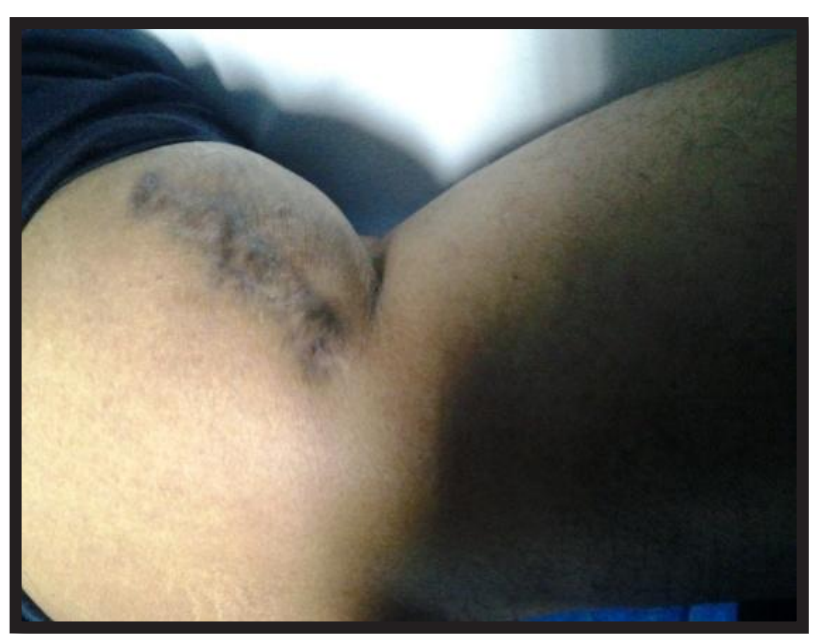

Figure 5. One year follow-up

In conclusion, EVLT has provided alternative for varicose vein treatment. High success rate, minor complication and minimally invasive technique are the advantages over traditional saphenous vein stripping found in this patient. Due to the aneurysmatic and thrombotic great saphenous varicose vein, we performed hybrid procedure. Short-term evaluation in this patient showed good results, yet further evaluation still needed. More advanced instrument yields better outcomes and lesser complications. There is a learning curve, meaning further development of the techniques used is mandatory.

\section{REFERENCES}

1. Kalra M, Gloviczki P. Fifteen years ago laser was supposed to open arteries, now it is supposed to close veins: what is the reality behind the tool? Perspect Vasc Surg Endovasc Ther. 2006;18(1):3-8.

2. Kalra M, Gloviczki P. Endovenous ablation of the saphenous vein. Perspect Vasc Surg Endovasc Ther. 2008;20(4):371-80.

3. Navarro L, Min RJ, Bone C. Endovenous laser: a new minimally invasive method of treatment for varicose veinspreliminary observations using an $810 \mathrm{~nm}$ diode laser. Dermatol Surg. 2001;27(2):117-22.

4. Proebstle TM, Lehr HA, Kargl A, et al. Endovenous treatment of the greater saphenous vein with a 940-nm diode laser: thrombotic occlusion after endoluminal thermal damage by laser-generated steam bubbles. J Vasc Surg. 2002;35(4):729-36.

5. Proebstle TM, Sandhofer M, Kargl A, et al. Thermal damage of the inner vein wall during endovenous laser treatment: key role of energy absorption by intravascular blood. Dermatol Surg. 2002;28(7):596-600.

6. Navarro L. Endovenous laser treatment with $810 \mathrm{~nm}$ to 980 $\mathrm{nm}$ wavelengths: method of action. Proceedings of ACP 19th Annual Conference; 2005; San Francisco.

7. Kabnick LS. Endovenous laser system $(980 \mathrm{~nm})$ for the treatment of saphenous vein insufficiency: 7611 limbs. Proceedings of ACP 19th Annual Conference; 2005; San Francisco.

8. Mozes G, Kalra M, Carmo M, Swenson L, Gloviczki P. Extension of saphenous thrombus into the femoral vein: a potential complication of new endovenous ablation techniques. J Vasc Surg. 2005;41(1):130-5.

9. Weiss RA, Weiss MA. Controlled radiofrequency endovenous occlusion using a unique radiofrequency catheter under duplex guidance to eliminate saphenous varicose vein reflux: a 2-year follow-up. Dermatol Surg. 2002;28(1):38-42.

10. Proebstle TM, Krummenauer F, Gül D, Knop J. Nonocclusion and early reopening of the great saphenous vein after endovenous laser treatment is fluence dependent. Dermatol Surg. 2004;30:174-8.

11. Timperman PE, Sichlau M, Ryu RK. Greater energy delivery improves treatment success of endovenous laser treatment of incompetent saphenous veins. J Vasc Interv Radiol. 2004;15(10):1061-3.

12. Proebstle TM, Gül D, Lehr HA, Kargl A, Knop J. Infrequent early recanalization of greater saphenous vein after endovenous laser treatment. J Vasc Surg. 2003;38(3):511-6.

13. Darwood RJ, Gough MJ. Endovenous laser treatment for uncomplicated varicose veins. Phlebology. 2009;24:50-61. 